\title{
DIAGNÓSTICO DIFERENCIAL DE SÍNDROME RESPIRATÓRIA EM TEMPOS DE PANDEMIA
}

\author{
DOI: $10.47224 /$ rm.v5i10.142
}

Clara Bensemann Gontijo Pereira ${ }^{2}$

Arthur Carvalho Faria'

Bruna Micheli Francischini Parizotto ${ }^{2}$

Luiza Bensemann Gontijo Pereira ${ }^{1}$

Luiza Bitarães Amorim²

Ana Carolina Bueno e Silva ${ }^{3}$

${ }^{1}$ Centro Universitário IMEPAC Araguari

${ }^{2}$ Pontifícia Universidade Católica de Minas (PUC Minas)

${ }^{3}$ Docente Orientador- Pontifícia Universidade Católica de Minas Gerais Campus Contagem e Betim e-mail de contato: clarabgontijo@gmail.com

F.A.N.M, masculino, 2 anos (DN: 20/05/2018), natural/procedente/residente em Belo Horizonte, Minas Gerais.

Acompanhante: M.A.N.M.(Mãe).

Data do primeiro atendimento: 03/05/2020

1. QP: "febre" há 2 dias.

2. HMA: Paciente comparece ao Pronto Socorro pediátrico acompanhado da mãe, a qual relata febre aferida de até 39ำ há 2 dias, de início súbito e associada a coriza e tosse seca. Relata uso de soro fisiológico nasal e administração de Paracetamol e Dipirona gotas (posologia não informada), apresentando piora do quadro térmico nas últimas 12 horas. Nega outros sintomas concomitantes. Grupo familiar sem queixas.

3. Antecedentes pré-natais, natais e pós-natais: Mãe 31 anos, G01P01A0, nega intercorrências na gestação, sorologias sem alterações. Evoluiu para ruptura prematura de membrana, com IG: 35semanas, PN: $2.500 \mathrm{~g}$, Comp: $46 \mathrm{~cm}, \mathrm{PC}: 32,5 \mathrm{~cm}$. Ficou no CPAP nasal por 4 horas. Icterícia neonatal com uso de fototerapia por 5 dias. Nega transfusão sanguínea, teste coraçãozinho, teste do pezinho ampliado, reflexo vermelho e triagem auditiva neonatal sem alterações.

4. Antecedentes de desenvolvimento e alimentares: alimentação e desenvolvimento adequados, entre o score Z -2 e Z -3 de peso, apesar de ser prematuro. Aleitamento misto desde a maternidade, sendo aleitamento materno até 10 mês. Ingere fórmula pela manhã e pela noite. Bom relacionamento escolar.

5. Antecedentes vacinais: cartão de vacinas atualizado, exceto contra Influenza em 2020. 
6. Antecedentes patológicos: IVAS (Infecção das Vias Aéreas Superiores) de repetição após entrar na escola. Fez uso de antimicrobiano 4 vezes no último ano para tratamento de otite média aguda. Pneumonia bacteriana com 1 ano e 2 meses.

7. Antecedentes familiares: mãe apresenta rinite alérgica e pai com histórico de bronquite na infância. Avós paternos hipertensos.

8. Antecedentes sociais: reside com os pais em casa própria. Pais em rotina de trabalho presencial, no contexto da pandemia. Criança fica com os avós para os pais trabalharem.

9. Ao exame físico:

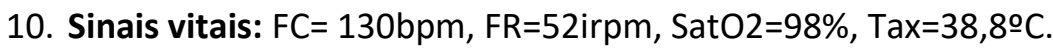

11. Antropometria: Peso: 10kg; Comprimento: $84 \mathrm{~cm}$; IMC: $14,17 \mathrm{~kg} / \mathrm{m} 2$.

12. Ectoscopia: REG (Regular Estado Geral), choroso, mucosas úmidas e normocoradas, acianótico, anictérico, fácies atípica, ausência de mal formações visíveis.

13. Rinoscopia: hiperemia de cornetos com secreção hialina.

14. Oroscopia: ausência de lesões em cavidade bucal, ausência de exsudato em tonsilas palatina e palato. Dentição decídua em bom estado de conservação.

15. Otoscopia: conduto auditivo com pequena quantidade de cerúmen, membranas timpânicas íntegras e de coloração cinza-perolada sem hiperemia ou abaulamentos.

16. AR: MVF (murmúrio vesicular fisiológico) com crepitações em terço inferior de pulmão direito. Esforço respiratório leve, com tiragem subdiafragmática e intercostal.

17. ACV: BRNF em $2 T$ (Bulhas rítmicas normofonéticas em 2 tempos), sem sopros, pulsos cheios e simétricos, perfusão capilar periférica menor que 2 segundos.

18. Reavaliação após dipirona: criança afebril, Tax 37 으, melhora do estado geral, sem esforço respiratório no momento, mas mantendo taquipneia de $46 \mathrm{irpm}$, SatO2 de $98 \%$ em a.a, FC $110 \mathrm{bpm}$.

\subsection{Hipóteses Diagnósticas}

1. Síndrome gripal, com possibilidades de Covid-19 e HIN1.

2. Pneumonia bacteriana.

3. Dengue.

\subsection{Exames complementares}

1. Radiografia de tórax: aumento de infiltrado e borramento de área cardíaca direita.

2. HMG: Hb: 11,3 mg/dL; Ht: 34\%; Leucócitos: 14.130/mm3 (S45/mm3 /L37/mm3 /M13,3/mm3); Plaquetas: $295.100 / \mathrm{mm} 3$

3. PCR: $137,9 \mathrm{mg} / \mathrm{L}$.

4. Dengue NS1: não reagente.

5. EAS: elementos dentro dos limites de normalidade.

6. RT-PCR para SARS-COV-2: aguardamos resultado. 
1. Criança de 2 anos e prematura.

2. Pandemia mundial de COVID-19.

3. Emprego dos pais sem possibilidade de home-office.

4. Condição econômica dos pais desfavorável para a realização do isolamento social corretamente.

5. Necessidade de ficar com os avós, faixa etária de risco na pandemia do

6. Mãe apresenta rinite alérgica.

7. Pai possui histórico de bronquite na infância.

1. Febre há dois dias.

2. Coriza.

3. Tosse.

4. Hiperemia de cornetos com secreção hialina.

5. Crepitação na ausculta pulmonar e taquipneia.

6. Antecedente de baixo peso e prematuridade.

\section{TRATAMENTO E EVOLUÇÃO}

Devido quadro febril prescrevemos Dipirona e Paracetamol.

Devido a prostração e PCR elevado, iniciamos com Amoxicilina com Clavulanato de Potássio e Azitromicina.

Prescrevemos Fosfato de Oseltamivir $30 \mathrm{mg}, 12 ; 12 \mathrm{~h}$, por 5 dias.

Evolução ambulatorial: Paciente apresentou melhora da febre e do estado geral com 72 horas de antimicrobiano. No sétimo dia da doença apresentou quadro de exantema micropapular, característico de pneumonia viral.

\section{Repetido os exames:}

- $\quad \mathrm{PCR}=16,7 \mathrm{mg} / \mathrm{L}$.

- Dengue: IgG e IgM negativos.

- HMG: Hb 12,4 mg/dL; Ht 34,9\% ; Leucócitos: 14.600/mm3 (S39/mm3/L42/ mm3/M12/ mm3); Plaquetas: $593.000 / \mathrm{mm} 3$.

- Resultado RT-PCR para SARS-COV-2: não reagente

- Suspendemos Amoxicilina com Clavulanato de Potássio.

- Resolução do exantema em 72 horas.

- Orientamos procurar unidade de saúde para imunização contra Influenza. 
- Orientamos sobre sinais de alarme: febre, vômitos, recusa alimentar, choro excessivo.

- Orientamos retorno imediato se piora clínica ou intercorrências.

- Orientamos sobre sinais de desconforto respiratório: dispneia, uso de musculatura acessória, TSC.

- Orientamos não ingerir medicamentos sem prescrição médica.

- Orientamos isolamento domiciliar.

- Orientamos uso de máscara

Nota: Realizada Notificação Imediata do caso no primeiro atendimento (febre + sintomas gripais).

Diagnóstico final: pneumonia viral.

\section{CONCLUSÃO}

Entende-se por síndrome gripal o comprometimento de vias aéreas superiores (estruturas compreendidas da cavidade nasal até a epiglote) associado a pelo menos um sinal de comprometimento sistêmico. A febre (temperatura acima de $37,8^{\circ} \mathrm{C}$ ) é o sinal mais proeminente em crianças com gripe; caracteriza-se, geralmente, por início súbito, com declínio por volta do terceiro dia e normalização em até 6 dias. Nas crianças, especialmente nas menores de três anos, a febre pode apresentar-se mais alta e prolongada. O pediatra deve suspeitar de síndrome gripal em toda criança com febre de início súbito, mesmo que referida, associado aos sintomas de vias aéreas superiores e um dos sintomas sistêmicos: mialgia, cefaleia ou artralgia. (SBP, 2020).

Os vírus são responsáveis pela maioria das PAC, em torno de $90 \%$ até um ano de idade e $50 \%$ em escolares. Destaca-se o Vírus Sincicial Respiratório, como o de maior incidência. Outros responsáveis em ordem de frequência são: Influenza, Parainfluenza, Adenovírus, Rinovírus, além de Metapneumovírus e Bocavírus, esses últimos associados à Síndrome da Angústia Respiratória (SARS) (SBP, 2018).

Geralmente os lactentes alimentados com leite de vaca ou fórmulas recebem a introdução da mamadeira, feito em posição mais horizontal, o que pode facilitar a entrada do líquido na tuba auditiva. Além disso, o leite tem componentes alérgenos e de alto risco de proliferação patogênica, que podem favorecer a infecção e o aparecimento de otites. Cabe ressaltar que o bebê que recebe aleitamento exclusivo ao seio da mãe durante os seis primeiros meses de vida, tem uma redução de $43 \%$ do risco de ter otite média nos dois primeiros anos de vida (BOWATTE et al,2015).

Além dessa proteção, os bebês que recebem leite materno até os seis meses de forma exclusiva e continuada até os dois anos, conforme recomendação da OMS recebem proteção extra contra doenças infecciosas e diarreias, uma vez que seu sistema imune - ainda imaturo - é protegido pelas substâncias 
imunomoduladoras, anti-inflamatórias e fatores de crescimento presentes no leite materno (LONNERDAL, 2014).

Neste contexto, tomamos as condutas iniciais recomendadas, através da prescrição de sintomáticos e antibióticos, além da solicitação de exames complementares. Ainda, fizemos orientações pertinentes ao momento: procurar UBS para imunização contra influenza; manter isolamento domiciliar; usar máscara, inclusive ressaltamos o risco de asfixia em crianças; procurar unidade de saúde imediatamente se piora do quadro; observar sinais de alarme (choro excessivo, recusa alimentar, febre, vômitos); manter adequada oferta de líquidos e alimentação saudável; observar sinais de desconforto respiratório e; não realizar automedicação.

\section{REFERÊNCIAS}

BOWATTE G, THAM R, ALLEM KJ, et al. Breastfeeding and childhood acute otitis media: a systematic review and meta-analysis. Acta Paediatr Suppl 2015; 104: 85-95. Disponível em:

https://onlinelibrary.wiley.com/doi/full/10.1111/apa.13151. Acesso em: 12 jun. 2020

LÖNNERDAL B. Bioactive Proteins in Human Milk: Health, Nutrition, and Implications for Infant Formulas. J Pediatr. 2016;173 Suppl: S4-S9. doi:10.1016/j.jpeds.2016.02.070. Disponível em: https://pubmed.ncbi.nlm.nih.gov/27234410/. Acesso em: 12 jun. 2020

SBP. Sociedade Brasileira de Pediatria. Atualização no tratamento e prevenção da infecção pelo vírus Influenza - 2020. Rio de Janeiro: SBP, 2020. Disponível em: https://www.sbp.com.br/fileadmin/user_upload/22445e-Diretriz_Atualiz_Trat_e_Prev_Infecc_Virus_Influenza_2020_1_.pdf. Acesso em: 09 jun. 2020

SBP. Sociedade Brasileira de Pediatria. Pneumonia adquirida na Comunidade na Infância. Rio de Janeiro: SBP, 2020. Disponível em: https://www.sbp.com.br/fileadmin/user_upload/Pneumologia_-_20981d-DC__Pneumonia_adquirida_na_comunidade-ok.pdf. Acesso em: 09 jun. 2020 